\title{
Black Horehound (Ballota nigra Linn) Induces Apoptosis in Prostate Cancer Cells (PC-3) Through Intrinsic Signalling Cascade
}

\author{
Selvaraj Jayaraman ${ }^{1, *}$, Ponnulakshmi Rajagopal' ${ }^{2}$ Vishnupriya Veeraraghavan ${ }^{1}$, Poonguzhali Sivagnanam $^{3}$, \\ Divya Ravikumar ${ }^{4}$, Sumetha Suga Deiva Suga ${ }^{5}$, Kavin Mozhi James ${ }^{3}$, Surapaneni Krishna Mohan ${ }^{6}$
}

Selvaraj Jayaraman ${ }^{1, *}$, Ponnulakshmi Rajagopal ${ }^{2}$, Vishnupriya Veeraraghavan ${ }^{1}$, Poonguzhali Sivagnanam ${ }^{3}$, Divya Ravikumar ${ }^{4}$, Sumetha Suga Deiva Suga ${ }^{5}$, Kavin Mozhi James ${ }^{3}$, Surapaneni Krishna Mohan $^{6}$

'Department of Biochemistry, Saveetha Dental College and Hospitals, Saveetha Institute of Medical and Technical Sciences, Saveetha University, Chennai - 600077 , INDIA. ${ }^{2}$ Central Research Laboratory, Meenakshi Academy of Higher Education and Research (Deemed to be University), West K. K. Nagar, Chennai-600 078, INDIA

${ }^{3}$ Department of Medical Surgical

Nursing, Panimalar College of Nursing,

Varadharajapuram, Poonamallee, Chennai -

600123 , INDIA

${ }^{4}$ Department of Obstetrics and Gynaecology

Panimalar Medical College Hospital \&

Research Institute, Varadharajapuram,

Poonamallee, Chennai - 600 123, INDIA.

${ }^{5}$ Department of Microbiology, Panimalar

Medical College Hospital \& Research Institute,

Varadharajapuram, Poonamallee, Chennai-

600123 , INDIA

${ }^{6}$ Department of Biochemistry, Panimalar

Medical College Hospital \& Research Institute,

Varadharajapuram, Poonamallee, Chennai 600 123, INDIA.

\section{Correspondence}

\section{Jayaraman Selvara}

Assistant Professor, Department of Biochemistry, Saveetha Dental College and Hospitals, Saveetha Institute of

Medical and Technical Sciences, Saveetha

University, Chennai - 600 077, INDIA

E-mail: jselvaendo@gmail.com

History

- Submission Date: 23-05-2020;

- Review completed: 11-07-2020;

- Accepted Date: 03-08-2020

DOI : 10.5530/pj.2020.12.190

Article Available online

http://www.phcogj.com/v12/i6

\section{Copyright}

(C) 2020 Phcogj.Com. This is an openaccess article distributed under the terms of the Creative Commons Attribution 4.0 International license.

\section{ABSTRACT}

Background: Prostate cancer is the most commonly diagnosed cancer among men. The disease varies widely in its clinical aggressiveness. Ballota nigra Linn (Black horehound) is a three-foot, perennial herb of the family Lamiaceae and it has been shown to have various pharmacological properties such as antioxidant, hypoglycemic, neuro-sedative, antibacterial, insecticidal and anticholinesterase activities. However, the elucidation of B.nigra for its anticancer activity in prostate cancer has not been studied so far. Methodology: Prostate cancer PC3 cells were treated with different concentrations of B.nigra $(50,100,200 \& 400 \mu \mathrm{g} / \mathrm{ml}$ ) for the analysis of $\mathrm{Bcl}-2$, Phosphorylation of $\mathrm{Bcl} 2$ ( $\mathrm{p}-\mathrm{Bcl} 2$ ) and tumor suppressor protein p53, Case pase-3 and caspase-9 in PC3 cells. Results: The B.nigra ethanolic leaf extract reduced the levels of anti apoptotic proteins (Bcl-2, p-Bcl2) and increased the level of tumor suppressor protein p53, caspase- 3 and 9 significantly $(p<0.05)$. Conclusion: Results of the study show that B.nigra has potential anticancer activity by modulating intrinsic activity of apoptotic signaling in PC-3 cells. Thus, B.nigra may have a potential therapeutic option for the treatment of prostate cancer. Key words: Ballota nigra, Prostate cancer, PC3, Apoptosis, Intrinsic pathway.

\section{INTRODUCTION}

Cancer is one of the most dreadful disease causing millions of death. It accounts for $\sim 7.6$ million deaths ( $13 \%$ of all deaths) worldwide, which is expected to rise to 13.1 million by $2030 .{ }^{1}$ Prostate cancer is the most commonly diagnosed cancer among men. The disease varies widely in its clinical aggressiveness. In some patients, prostate cancer metastasis rapidly, killing the patient within a year of initial clinical presentation, whereas other patients may live for many years with localized disease without apparent metastases. ${ }^{2}$ Androgen and androgen receptor play a major role in prostate cancer. Steroid hormone androgens contribute to the initiation and promotion of multistage carcinogenesis through binding to hormone receptors. ${ }^{3}$ Androgen ablation has been the standard form of therapy for advanced prostate cancer for over 50 years. This therapy targets only androgen-dependent cells leaving the androgenindependent cells, so, a majority of patients will not respond to this therapy. ${ }^{4}$ Apoptosis or active cell death is a process whereby cells die in response to specific signals. It is a physiological process that is essential for normal tissue development and maintenance of hemostasis. Through this process, damaged, unattached, mutant and aged cells are eliminated. ${ }^{5}$ Imperfection in the apoptotic pathway will lead to the growth of tumors and the development of resistance to anticancer therapies. In fact, suppression of apoptosis is considered as one of the hallmark of cancers. ${ }^{6}$ Current strategy of apoptotic target drugs targets at extrinsic pathway proteins or intrinsic pathway proteins. Extrinsic and intrinsic pathways are the two most important signaling pathways mediating apoptosis. Extrinsic pathway is mediated by cell surface death receptor and intrinsic is initiated in mitochondria. ${ }^{7}$ For both the pathways, caspases are the regulatory protein which cleaves a variety of proteins essential for cell survival, such as cytoskeletal proteins and DNA repair proteins. ${ }^{8}$

Intrinsic apoptotic pathway is mainly governed by Bcl- 2 family proteins. This family contains both proand antiapoptotic proteins. The antiapoptotic protein $\mathrm{Bcl}-2$ is an oncogene that contributes to neoplastic progression by enhancing tumor cell survival through inhibition of apoptosis. In prostate cancer, this Bcl-2 is overexpressed which leads to progression of metastatic prostate cancer through inhibition of apoptotic cell death. ${ }^{9}$ This Bcl-2 overexpression also causes resistance to heat-shock stress, several chemotherapies and radiotherapy. ${ }^{10}$ Although great advancements have been made in the treatment and control of cancer progression, significant deficiencies and space for improvement remain. A number of undesired side effects sometimes occur during chemotherapy. ${ }^{11}$ Compared with synthetic compounds, natural products provide inherent larger-scale diversity and have been the major resource of bioactive agents for new drug discovery. ${ }^{12}$ In research point of view, natural products are rapidly being utilized as source for drug discovery and development, because of its comparatively safe and low cost. Anticancer agents from natural source have a long history in folk medicine and it has

Cite this article: Jayaraman $S$, Rajagopal $P$, Vishnupriya $V$, Sivagnanam $P$, Ravikumar $D$, et al. Black Horehound (Ballota nigra Linn) Induces Apoptosis in Prostate Cancer Cells (PC-3) Through Intrinsic Signalling Cascade. Pharmacogn J. 2020;12(6):1377-82. 
been combined into traditional and allopathic medicine. Nowadays, approximately $28 \%$ of modern medicines are derived from medicinal plants. ${ }^{13}$

There are several drugs derived from the plant origin are used in market to treat cancer which includes vinca alkaloids- vinblastine and vincristine, epipodophyllotoxins (etoposide, teniposide), taxanes (paclitaxel, docetaxel), and camptothecin derivatives (topotecan, irinotecan).${ }^{14}$ Medicinal plants are at interest to the field of novel drug development, as most of the drug industries depend on medicinal plants for the production of novel bioactive compounds.

Ballota nigra Linn (Black horehound) is a three-foot, perennial herb of the family Lamiaceae which grows in waste ground, hedgerows, woods and shady places, preferring nitrogen-rich, moist, rather loose soil. The plant is found in Mediterranean and central Asia and distributed all over the Europe and the eastern United States and it is commonly known as Black horehound in English. ${ }^{15}$ The aerial parts of the plant have been reported to contain various chemical constituents such as flavonoids, diterpenoids, phenylpropanoid glycosides, volatile oil and fatty acid. The whole plant is reported to exhibit various pharmacological activities such as antioxidant activity, hypoglycemic effect, neurosedative effect, antibacterial, insecticidal andanticholinesterase activity. ${ }^{16,17}$ Rigano et $a l .{ }^{18}$ reported the cytotoxicity of $B$. nigra against two human cancer cells, hepatoma HepG2 cell line and breast cancer MCF-7 cell line. However, the elucidation of B.nigra on prostate cancer has not been studied so far. Hence, the proposed study the ethanolic extract of B.nigra was an attempt whether the selected plant extract could inhibit intrinsic pathway in human prostate cancer cells.

\section{MATERIALS AND METHODS}

Chemical and Reagents: All the chemicals used in this study were of extra pure and analytical grade. CA and dimethyl sulfoxide (DMSO) and 3-(4,5-dimethylthiazol-2-yl)-2,5- diphenyltetrazolium bromide (MTT) were purchased from Sigma Chemical Pvt., Ltd. (St. Louis, MO., USA), polyvinylidene difluoride (PVDF) membrane was purchased from Millipore (Billerica, Massachusetts, USA). Trypsin-EDTA, fetal bovine serum (FBS), antibiotics-antimycotics, Roswell Park Memorial Institute (RPMI) medium, and phosphate-buffered saline (PBS) were purchased from Gibco, United States. Primary antibodies against B-cell lymphoma-2 (Bcl-2), p-Bcl-2, p53, Case pase-3 and caspase- 9 were purchased from cell signaling (Danvers, Massachusetts, United States) and Santa Cruz Biotechnology (Texas, United States). The secondary antibodies, horseradish peroxidase (HRP) conjugated rabbit antimouse IgG, and goat-anti-rabbit IgG were obtained from Santa Cruz Biotechnology (Texas, United State).

\section{Procurement and maintenance of PC-3Cell line}

PC-3 cell lines were obtained from the National Centre for Cell Science (Pune, India). The cells were grown in T-25 culture flasks in RPMI medium supplemented with $10 \%$ FBS with $1 \%$ penicillin/streptomycin and $1 \%$ amphotericin B. Cells were maintained at $37^{\circ} \mathrm{C}$ in a humidified atmosphere containing $5 \% \mathrm{CO}_{2}$. On attaining the confluence, the cells were trypsinized and plated.

\section{Cell viability Test}

The cell viability assay was performed by MTT assay, which determines mitochondrial activity in living cells. Cells were seeded in a 96-well plate at a density of $5 \times 10^{4}$ cells/well and incubated for $24 \mathrm{~h}$ at $37^{\circ} \mathrm{C}$, $5 \% \mathrm{CO}_{2}$ incubator. After attachment, cells were washed with PBS and then incubated with serum-free medium for 6-12 h. EA was dissolved in DMSO with different concentration EA $(50,100,200$ and $400 \mu \mathrm{g} / \mathrm{ml})$ and added to the cells. After the treatment period, $20 \mathrm{ml}$ medium was removed and $20 \mathrm{ml}$ of MTT was added and incubated for $30 \mathrm{~min}$. Then, $100 \mathrm{ml}$ of DMSO was added to solubilize the crystals and was kept in dark for $10 \mathrm{~min}$. The intensity of color development was measured at $570 \mathrm{~nm}$ in ELISA reader. The cell viability was calculated as follows: Cell viability $=$ absorbance of treated cells/absorbance of control cells $\times 100 \%$. Cell lysate preparation PC-3cells were placed in a Petri dish of $100 \mathrm{~mm} \times 20 \mathrm{~mm}$ at a density concentration of $1 \times 10^{4}$ cells/Petri dish and grown in RPMI medium, respectively, with 10\% FBS. After $24 \mathrm{~h}$ ( $70-80 \%$ confluent), both the cells were treated with DAM (10 and $100 \mathrm{mM} / \mathrm{ml}$ ) for $24 \mathrm{~h}$. At the end of the treatment, cells were washed once with ice-cold PBS and added $300 \mathrm{ml}$ of ice cold RIPA buffer with protease inhibitors. The Petri dishes were placed on ice and left on a shaker rocking for $2 \mathrm{~min}$. Cell lysates were collected into a $1.5-\mathrm{ml}$ tube and centrifuged at $14,000 \times \mathrm{g}$ for $10 \mathrm{~min}$ at $4^{\circ} \mathrm{C}$. The supernatant was separated and the protein concentration of supernatants was determined.

\section{Protein expression analysis}

\section{Preparation of cell lysate}

PC-3 cells were plated in a petri-dish of $100 \mathrm{~mm} 20 \mathrm{~mm}$ at a density concentration of $1 \times 10^{6}$ cells/petri-dish and grown in RPMI medium, respectively, with $10 \%$ FBS. After $24 \mathrm{~h}$ ( $\sim 70-80 \%$ confluent), both the cells were treated with B.nigra $(200 \mu \mathrm{g} / \mathrm{ml})$ for $24 \mathrm{~h}$. At the end of treatment, cells were washed once with ice-cold PBS and added $300 \mathrm{ml}$ of ice-cold RIPA buffer with protease inhibitors. The petri-dishes were placed on ice and left on a shaker rocking for $2 \mathrm{~min}$. Cell lysates were collected into a $1.5-\mathrm{ml}$ tube and centrifuged at $14000 \mathrm{~g}$ for $10 \mathrm{~min}$ at $4^{\circ} \mathrm{C}$. The supernatants were separated and the protein concentration of supernatants was determined.

\section{Western blotting analysis}

\section{Protein isolation and western blotting}

For protein isolation, $100 \mathrm{mg}$ of adipose tissue from control and experimental animals were used. To $100 \mathrm{mg}$ of adipose tissue, $1 \mathrm{ml}$ of buffer A ( $5 \mathrm{mM} \mathrm{NaN} 3,0.25 \mathrm{M}$ sucrose, $10 \mathrm{mM} \mathrm{NaHCO} 3)$ was added and homogenized and centrifuged at $1300 \times \mathrm{g}$ at $4{ }^{\circ} \mathrm{C}$ for $10 \mathrm{~min}$. The supernatant was separated and again centrifuged at $4{ }^{\circ} \mathrm{C}$ for $15 \mathrm{~min}$ at $12,000 \times \mathrm{g}$. The final supernatant was specimened as a total protein to assess the post-receptor insulin signaling molecules. The protein estimation was done based on the method of Lowry, et al. ${ }^{19}$

By using sodium dodecyl sulfate-polyacrylamide gel electrophoresis ( $10 \%$ gel), The lysate proteins $(50 \mu \mathrm{g} / \mathrm{lane})$ were separated and transferred to polyvinylidene difluoride (PVDF) membrane (BioRad Laboratories Inc) by electroblotting. $5 \%$ of non-fat dry milk was used to block the membranes and tagged with the primary antibodies (1:1000 dilutions). The membrane was subjected to repeated wash with TBS- $\mathrm{T}$ for three times and incubated with 1:5000 dilution of horseradish peroxidase-conjugated rabbit-anti-mouse or goat-antirabbit secondary antibodies (GeNei, Bangalore, India) for $1 \mathrm{~h}$. After incubation, the membrane was again subjected to repeated wash with TBS and TBS-T three times. The protein bands were visualized using a sophisticated Chemiluminescence detection system (Thermo Fisher Scientific Inc., Waltham, MA, USA), the specific signals were found and protein bands were captured and quantified by Chemidoc and Quantity One image analysis system Bio-Rad Laboratories, CA respectively. Later, the membrane was incubated at $50^{\circ} \mathrm{C}$ in stripping buffer $(50 \mathrm{ml}$, containing $62.5 \mathrm{mM}$ of Tris- $\mathrm{HCl}$ (pH 6.7), $1 \mathrm{~g}$ of SDS and $0.34 \mathrm{ml}$ of $\beta$-mercaptoethanol) for $30 \mathrm{~min}$. Then, the membranes were reprobed with $\beta$-actin antibody (1:5000). $\beta$-actin was used as invariant control.

\section{STATISTICAL ANALYSIS}

Data were expressed as mean \pm standard error of the mean. Statistical analyses were performed using one-way ANOVA followed by Duncan's tests for comparison between treatment and control values using the 
Statistical Package for Student version 17.0 (SPSS Inc., Chicago, IL) software $p<0.05$ was considered to be statistically significant.

\section{RESULTS}

\section{Effect of B.nigra on the cell viability in PC-3 cells}

B.nigra reduced the viability of PC-3 cells in a dose-dependent manner $(50,100,200$ and $400 \mu \mathrm{g})$ concentration. 50 $\mathrm{g}$ dose did not respond in cell growth inhibition whereas 100,200 and 400 could effectively reduce growth significantly $(\mathrm{p}<0.05)$. However, it significantly decreased the viability of PC-3 cells in $24 \mathrm{~h}$ with $\mathrm{IC}_{50}$ values of 200 and $400 \mu \mathrm{g} / \mathrm{ml}$, respectively (Figure 1). Hence, $400 \mu \mathrm{g}$ concentrations was used for further analysis of protein expression of apoptosis signaling cascade.

\section{Effect of B.nigra on $\mathrm{Bcl}-2$ and $\mathrm{p}-\mathrm{Bcl}-2$ protein expression in PC-3 Cells}

To examine the status of intracellular signaling molecules in the B.nigra-treated cells, protein expression analysis was performed. B.nigra treatment significantly decreased $(p<0.05)$ the antiapoptotic proteins such as Bcl-2 and p-Bcl-2 (Figure 2).

\section{Effect of B.nigra on p53, Case pase-3 and caspase-9 Protein Expression in $\mathrm{PC}-3$ cells}

B.nigra treated PC-3 cells showed a significant increase $(p<0.05)$ in p53, casepase-3 \& 9 protein expression stating that B.nigra has play significant role in the regulation of tumor suppressor protein activation (Figure 3).

\section{DISCUSSION}

Apoptosis is a key process in cancer development. Evading apoptosis is one of the hallmarks of cancer. The apoptotic pathway plays a major role in prostate cancer as well. Prostate cancer treatment initially starts with androgen withdrawal, where many of the cancer cells die through apoptosis. But in some cases the cells derive resistance to this treatment and leads to metastatic prostate cancer. ${ }^{20}$ Hence, in this study we aimed to manage this advanced stage of cancer by targeting apoptotic pathway.
As we were targeting advanced stage of cancer, hormone-independent cell line PC-3 was selected for the study.

Intrinsic pathway of apoptosis is one of the pathways activated by many cytotoxic drugs. Bcl-2 members family play a major role in the intrinsic pathway and this family contains 25 pro and antiapoptotic members which interact to maintain the balance between newly forming and old dying cells. ${ }^{21}$ These proteins are classified into three subfamilies. Antiapoptotic subfamily contains the Bcl-2, Bcl- XL, Bcl-w, Mcl-1, Bfl1/A-1 and Bcl-B proteins which suppress apoptosis, some proapoptotic proteins such as Bax, Bak and Bok, other pro-apoptotic proteins such as Bim Bad and Bid.

The antiapoptotic proteins are over expressed in prostate cancer. These proteins heterodimerize with pro-apoptotic protein such as Bax/Bak, which will prevent the cell death.

Drugs have been used for prostate cancer targeting the antiapoptotic proteins. These drugs induce the activation of tumor suppressor protein $\mathrm{p} 53$ thereby increase the expression of pro-apoptotic protein and reducing the expression of antiapoptotic protein. ${ }^{22}$ The same mechanism was observed in the B.nigra treated the PC-3 cells of the present study. There was an increase in the level of p53 and decrease in the antiapoptotic proteins level of $\mathrm{Bcl}-2$ and $\mathrm{p}$-Bcl-2. This clearly denotes that B.nigra promotes apoptosis by the intrinsic pathway.

This hypothesis is well determined through the analysis of caspase expression. Caspases serve as a primary mediator of apoptosis located in the cytosolic space..$^{23}$ In the present study, the treatment of B.nigra could lead to the release of cytochrome $c$ from mitochondrial space which would have been combined with an adaptor molecule apoptosis protease activating factor 1 and also with an inactive initiator caspase, pro-caspase- 9 within a multiprotein complex called the apoptosome. ${ }^{24}$ This apoptosome would have caused a series of caspase activation which starts from 9 to 3, 6, 7 that ultimately would have caused apoptosis. Hence, it clearly depicted that B.nigra activates apoptosis by the intrinsic pathway. It is noteworthy to suggest the following hypothesis for the mechanism for apoptosis caused by B.nigra.

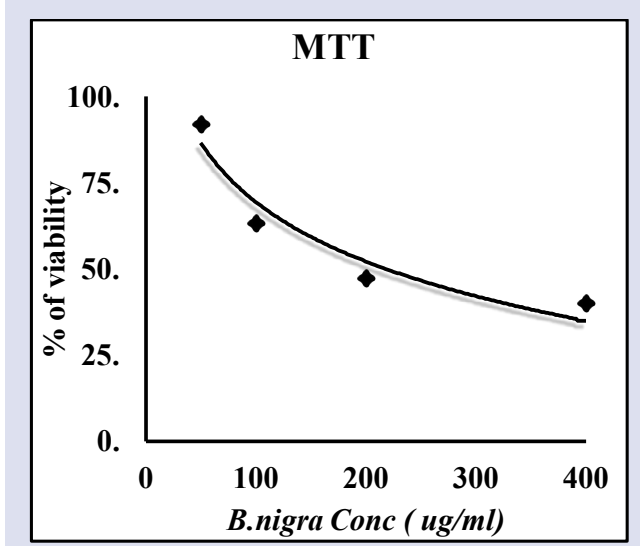

Figure 1: Effect of B.nigra extract on the viability of prostate cancer cells. PC-3 cells were cultured in RPMI medium supplemented with $10 \%$ FBS and incubated with indicated concentrations of DGT for $24 \mathrm{~h}$. For cell viability assay, cells were exposed to different doses $(50,100,200$ and $400 \mu \mathrm{g} / \mathrm{ml})$ of DGT for $24 \mathrm{~h}$. DGT inhibits growth (as determined by MTT assay) of human prostate cancer cells. Each bar represents the mean \pm SEM of five independent observations and the statistical significance between control and the treated groups at $p<0.05$ level. 

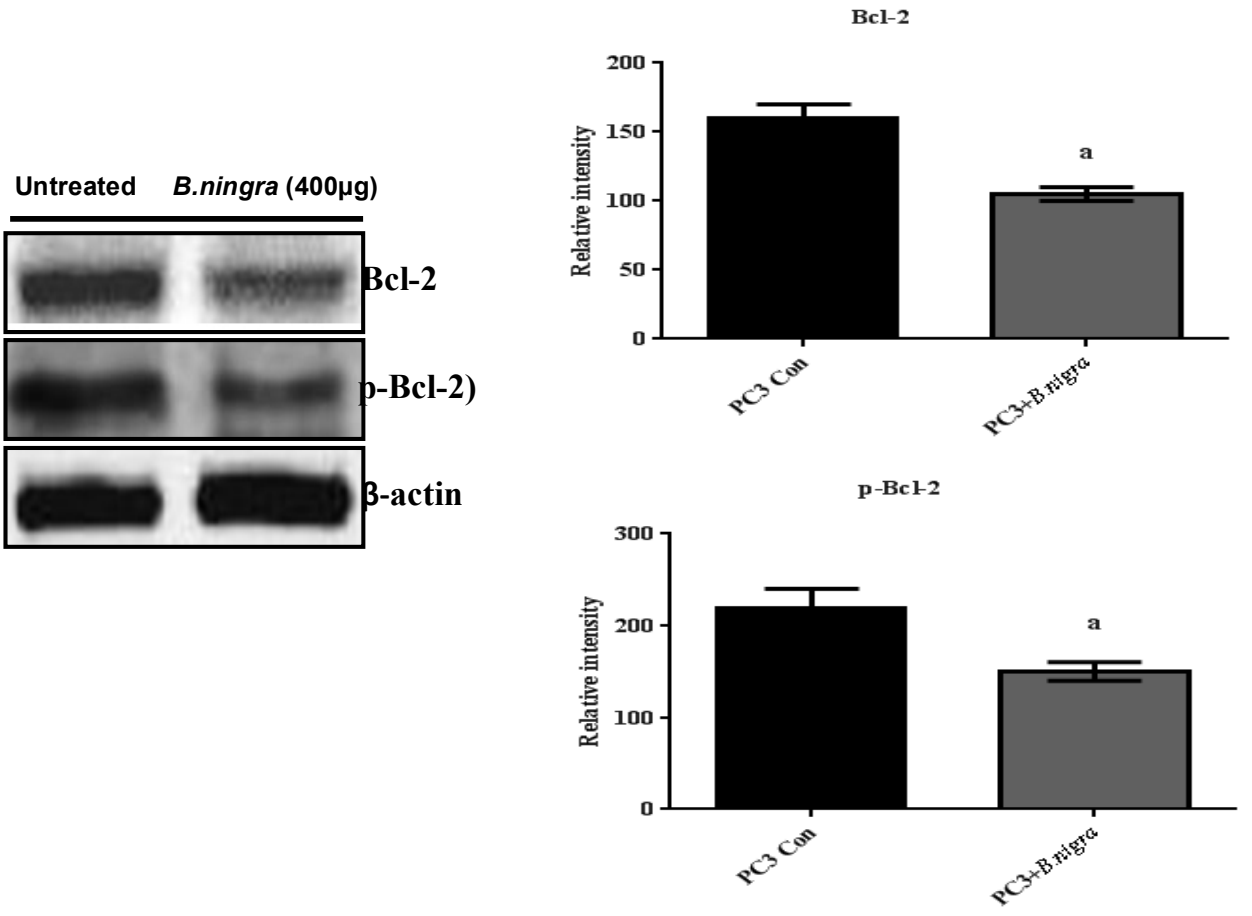

Figure 2: Effect of B.nigra on anti-apoptotic proteins in PC-3 cells. Each bar represents the Mean \pm SEM of five observations. Significance at $p<0.05$. a- compared with untreated cancer cells.
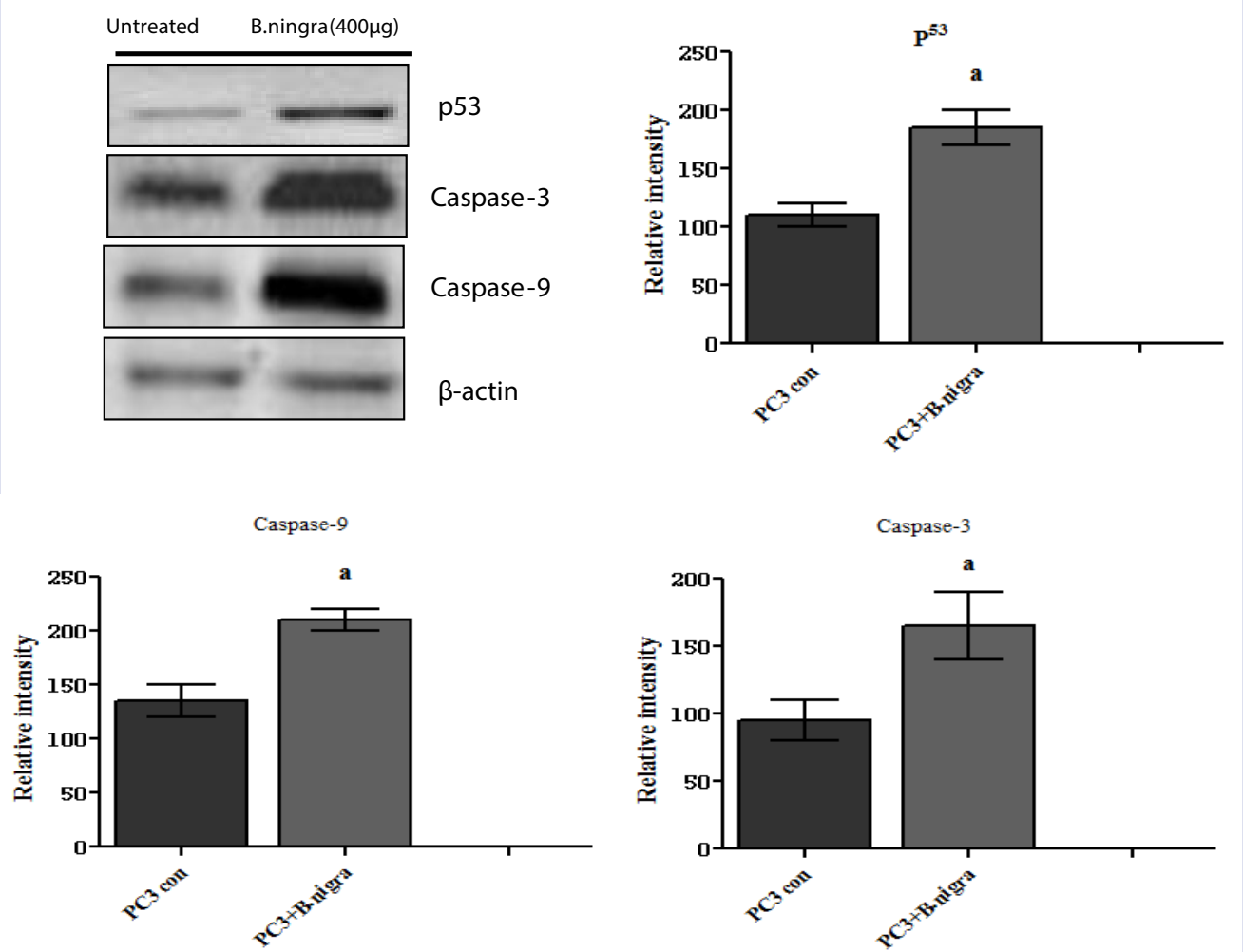

Figure 3: Effect of B.nigra on p53, Casepase-3 and Casepase-9 protein expression in PC-3 cells. Each bar represents the Mean \pm SEM of five observations. Significance at $p<0.05$. a- compared with untreated cancer cells. 
In present study, B.nigra treated PC-3 cells showed a significant decrease in anti apoptotic makers (Bcl-2 and $\mathrm{p}-\mathrm{Bcl}-2)$ and increase in the $\mathrm{p} 53$, caspase-3/9 in PC-3 cells recorded in the present study showing that B.nigra has potenail cytotoxic activity. In view of these findings Rigano, et al..$^{18}$ reported the cytotoxicity of B.nigra against other two human cancer cells, hepatoma HepG2 cell line and breast cancer MCF-7 cell lines.

\section{CONCLUSION}

The current study proved that Bollata nigra strongly inhibits the growth of prostate cancer cells by interfering with the apoptotic pathway. It down-regulated the antiapoptotic proteins while up-regulated the pro-apoptotic proteins and thereby paved the way to cell death. The caspase- 9 and caspase- 3 activation proved that B.nigra acts through intrinsic apoptotic pathway. Thus, B.nigra potent chemotherapeutics compound for treating prostate cancer. Further experiments through animal model and clinical trial will lead B.nigra to be a potent drug in future.

\section{CONFLICTS OF INTEREST}

None declared.

\section{REFERENCES}

1. Thun MJ, De Lancey JO, Center MM. The global burden of cancer: priorities for prevention. Carcinogenesis. 2010;31:100-10.

2. Nair R, Withington J, Ghos S, Henderson A. Early detection and patient risk stratification in prostate cancer. In: Ashutosh tewari, ed. Prostate cancer: a comprehensive perspective. London, Heidelberg, New York, Dordrecht: Springer; 2013:34-45

3. Henderson BE, Feigelson HS. Hormonal carcinogenesis. Carcinogenesis. 2000;21:427-33.

4. Brawer MK. Hormonal therapy for prostate cancer. Rev Urol. 2006;8:S1-9.

5. Isaacs JT, Lundmo PI, Berges R. Androgen regulation of programmed death of normal and malignant prostatic cells. J Androl. 1992;13:457-64.

6. Renehan AG, Booth C, Potten CS. What is apoptosis, and why is it important. BMJ. 2001;322:1536-8.
7. Hanahan D, Weinberg RA. The hallmarks of cancer. Cell. 2000;100:57-70

8. Khan KH, Blanco-Codessido M, Molife LR. Cancer therapeutics: targetting the apoptotic pathway. Crit Rev Oncol Hematol. 2014;90:200-19.

9. Cryns V, Yuan J. Proteases to die for. Genes Dev. 1998;12:1551-70.

10. Pon Nivedha R, Selvaraj J, Lalitha KG, Rajalakshmi M. Effects of dihydroxy gymnemic triacetate (DGT) on expression of apoptosis associated proteins in human prostate cancer cell lines (PC3). J Recept Signal Transduct Res. 2015;35(6):605-12.

11. Desai AG, Qazi GN, Ganju RK. Medicinal plants and cancer chemoprevention. Curr Drug Metab. 2008;9(7):581-91

12. Atanasov AG, Waltenberger B, Pferschy-Wenzig EM. Discovery and resupply of pharmacologically active plant-derived natural products: A review. Biotechno Adv. 2015;33(8):1582-614.

13. Yuan H, Ma Q, Ye L, Piao G. The Traditional Medicine and Modern Medicine from Natural Products. Molecules. 2016;21(5):559.

14. Taneja, SC.; Qazi, GN. Bioactive Molecues in Medicinal Plants: A perspective in their therapeutic action, in Drug discovery and development. Chorghade, MS. editor. John Wiley and Sons, Inc; 2007. p. 1-50.

15. Lazkov, G.A, Sultanova, BA. Checklist of vascular plants of Kyrgyzstan. Norrlinia 2011;24:1-166

16. Bertrand MC, Tillequin F, Bailleul F. Two major flavonoids from Ballota nigra Biochemical Systematics and Ecology. 2000;28:1031-3.

17. Vrchovska V, Spilkova J, Valentao P, Sousa C, Andrade PB, Seabra RM Antioxidative properties and phytochemical composition of Ballota nigra infusion. Food Chem.2007;105:1396-403.

18. Rigano D, Marrelli M, Formisano C. Phytochemical profile of three Ballota species essential oils and evaluation of the effects on human cancer cells. Nat Prod Res. 2017;31(4):436-44.

19. Lowry OH, Rosebrough NJ, Farr AL, Randall RJ. Protein measurement with the Folin phenol reagent. J Biol Chem. 1951;193:265-75.

20. Raffo AJ, Perlman H, Chen M-W. Overexpression of bcl-2 protects prostate cancer cells from apoptosis in vitro and confers resistance to androgen depletion in vivo. Cancer Res. 1995;55:4438-45.

21. Zielinski RR, Eigl BJ, Chi KN. Targeting the apoptosis pathway in prostate cancer. Cancer J. 2013;19:79-89.

22. Reed JC, Pellecchia M. Apoptosis-based therapies for hematologic malignancies. Blood. 2005;106:408-18.

23. Fischer U, Schulze-Osthoff K. Apoptosis-based therapies and drug targets. Cell Death Differ. 2005;12:942-61.

24. Van Loo G, Saelens X, Matthijssens F. Caspases are not localized in mitochondria during life or death. Cell Death Differ. 2002;9:1207-11. 


\section{GRAPHICAL ABSTRACT}

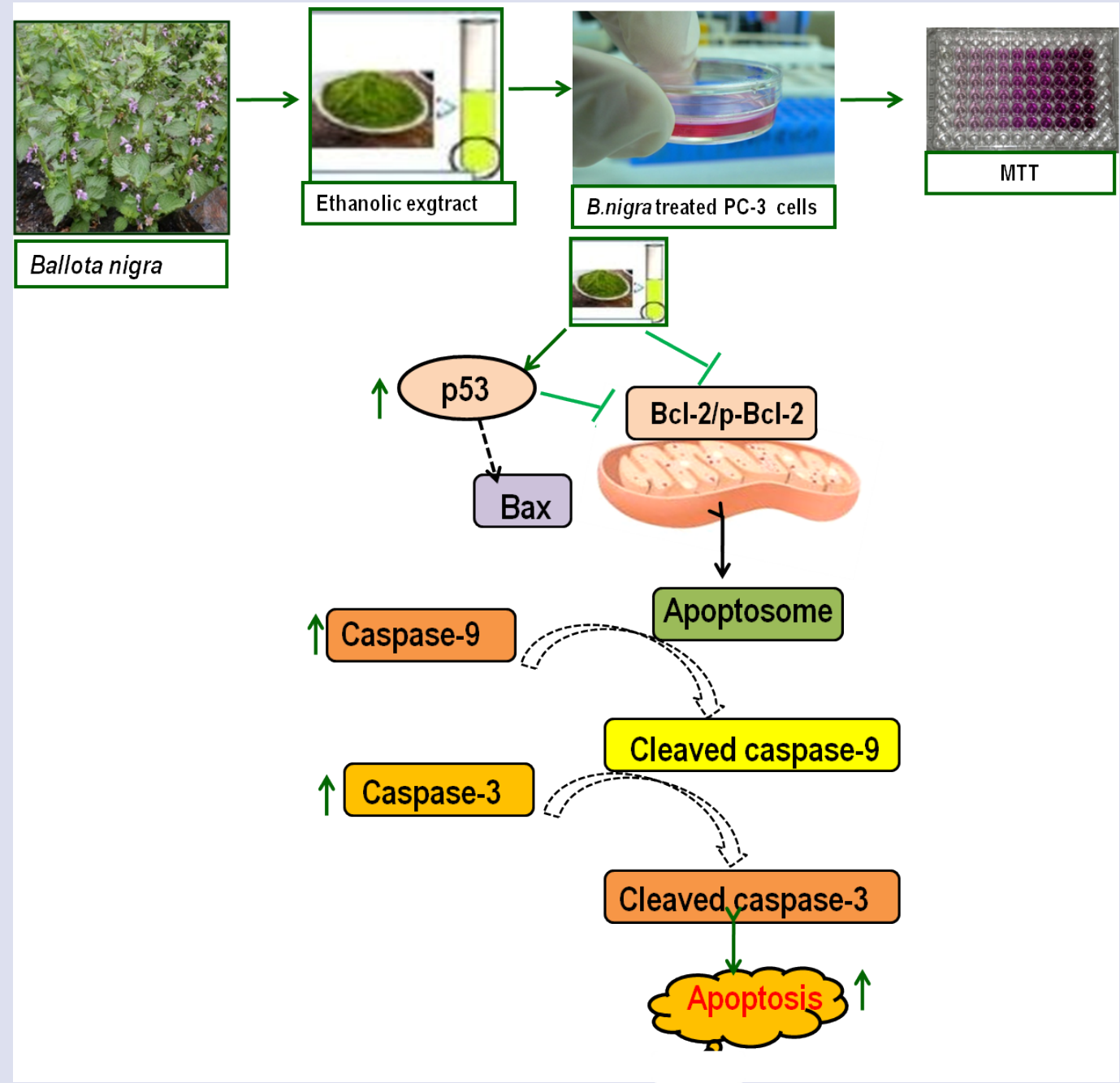

Cite this article: Jayaraman S, Rajagopal P, Vishnupriya V, Sivagnanam P, Ravikumar D, et al. Black Horehound (Ballota nigra Linn) Induces Apoptosis in Prostate Cancer Cells (PC-3) Through Intrinsic Signalling Cascade. Pharmacogn J. 2020;12(6):1377-82. 